\title{
Effects of Uneven Vertical Distribution of Soil Salinity on Blossom-end Rot of Tomato Fruit
}

\author{
Sheng Chen, Zhenchang Wang ${ }^{1}$, Zhanyu Zhang, Xiangping Guo, \\ Mengyang Wu, and Ghulam Rasool \\ College of Water Conservancy and Hydropower Engineering, Hohai \\ University, Nanjing 210098, China
}

\author{
Rangjian Qiu \\ Jiangsu Provincial Key Laboratory of Agricultural Meteorology, College of \\ Applied Meteorology, Nanjing University of Information Science and \\ Technology, Nanjing 210044, China
}

\author{
Xiaojun Wang \\ Nanjing Hydraulic Research Institute, State Key Laboratory of Hydrology- \\ Water Resources and Hydraulic Engineering, Nanjing 210029, China
}

Additional index words. BER incidence, $\mathrm{Ca}^{2+}$ concentration, $\mathrm{Na}^{+}$concentration, selectively absorption, straw isolation layer

\begin{abstract}
Soil salinity influences plant growth and crop yield significantly. Former studies indicated that uneven salt distribution in the root zone could relieve salt stress. But, how uneven salt distribution influences $\mathrm{Na}^{+}$and $\mathrm{Ca}^{2+}$ concentration in the stem, leaf, and fruit and whether this influence would bring effects on fruit blossom-end rot (BER) still needs to be further studied. Under consideration of this, pot experiment with four treatments, $T_{1: 1}, T_{1: 5}, T_{2: 4}$, and $T_{3: 3}$, was conducted by setting the upper soil layer salinity at $1 \%, 1 \%, 2 \%$, and $3 \%$ and the lower soil layer at salinities of $1 \%$, $5 \%$, $4 \%$, and $3 \%$, respectively. Compared with the uniform salt concentration in the root zone $\left(T_{3: 3}\right.$ treatment), the incidence of BER in the $T_{1: 5}$ and $T_{2: 4}$ treatments decreased by $60 \%$ and $35 \%$, respectively. The fruit $\mathrm{Na}^{+}$concentration and $\mathrm{Na}^{+} / \mathrm{Ca}^{2+}$ ratio were positively correlated with the incidence of BER. The value of the upper-root selective absorption $\mathrm{Ca}^{2+}$ over $\mathrm{Na}^{+}\left(\mathrm{S}_{\mathrm{Ca} / \mathrm{Na} \text { (upper root) }}\right)$ for $\mathrm{T}_{1: 5}$ was 0.8 times more than that of $\mathrm{T}_{1: 1}$. The results showed that the incidence of BER was positively correlated with root dry matter and $\mathrm{S}_{\mathrm{Ca} / \mathrm{Na} \text { (root) }}$ weighted mean salinity. The overall results suggested that uneven salt distribution in the root zone could promote the $\mathrm{Ca}^{2+}$ absorption, $\mathrm{Ca}^{2+} / \mathrm{Na}^{+}$ratio, and selective absorption $\mathrm{Ca}^{2+}$ over $\mathrm{Na}^{+}$and consequently decrease the incidence of $\mathrm{BER}$ in tomato fruit.
\end{abstract}

Salt stress adversely affects plant growth and causes $7 \%$ decrease in crop yield all over the world (Latef and Chaoxing, 2011; Maggio et al., 2004). Plants suffer from salt stress in the following ways: 1) the decrease in the osmotic potential in the rooting medium makes it difficult for roots to absorb water, 2) the toxic effect of a high concentration of $\mathrm{Na}^{+}$triggers a series of toxicity events and causes damage to the systems that absorb and use $\mathrm{Ca}^{2+}$ ion, and it negatively affects crop growth and development, because $\mathrm{Ca}^{2+}$ is essential for various physi-

Received for publication 30 Jan. 2017. Accepted for publication 31 May 2017.

We are grateful for grants from National Key Research and Development Program of China during the 13th Five-Year Plan Period (2016YFC0400208), the National Natural Science Foundation of China (51309080, 51079042), and the Fundamental Research Funds for the Central Universities (2013B06014 and 2015B34414).

${ }^{1}$ Corresponding author. E-mail: 15950467154@ 163.com. ological and biochemical processes (Ebrahimi and Bhatla, 2012; Gama et al., 2007; Hilge, 2012; Munns and Tester, 2008). Furthermore, a high rate of BER occurrence has been associated with a low $\mathrm{Ca}^{2+}$ concentration in the fruit tissue (Ho and White, 2005).

Overirrigation with fresh or brackish water before planting is a common practice for growing crops in areas with high salinity (Dong et al., 2010). Using this approach, excess irrigation reduces the surface soil salinity to maintain plant growth. However, this method does not always work because salts will move upward by capillary rise in response to higher potential evapotranspiration and accumulate near the soil surface (Imada et al., 2015; Rengasamy, 2006; Salama et al., 1999). To solve this problem, a capillary barrier (CB) is often chosen to prevent salt accumulation in the surface soil layer, which is a phenomenon of hydraulic for disrupted capillary water continuity (Ityel et al., 2014). Rooney et al. (1998) found a decrease of $66 \%$ in capillary water moving upward, which led to a lesser soil salt content in the surface by using a $\mathrm{CB}$ above the shallow groundwater table. When compared with the treatment without a CB, Ityel et al. (2012) found that the buried isolation layer could lead to a $24 \%$ increase in yield of pepper plants. In addition, recent studies indicated that root of plants could easily penetrate through the isolation layer if it was designed properly (Chen et al., 2016; Dara et al., 2015). Under CB conditions, soil salt always moves downward with water (Zhao et al., 2014, 2016). Once the root penetrates through the layer, the distinct salt concentrations for the upper and lower soil layers could result in the vertical heterogeneous distribution of salinity in the root environment (Qiao et al., 2006; Zhang et al., 2010). The results of former researchers had indicated that when compared with uniform salinity, an unequal salt distribution in the soil would improve the growth of oranges (Zekri and Parsons, 1990), cucumbers (Sonneveld and de Kreij, 1999), tomatoes (Tabatabaie et al., 2004), and Atriplex nummularia (Bazihizina et al., 2009). Our former study also showed that an uneven salt distribution in the soil could enhance the growth of tomatoes (Chen et al., 2016). Recent studies of Dong et al. $(2008,2010)$ showed that under plastic mulching, furrow seeding could increase the cotton yield in saline environments because this method resulted in an unequal salt distribution in the root zone. Previous studies mainly focused on the responses of plants to the horizontal uneven salt distribution in the root zone (Bazihizina et al., 2009; Dong et al., 2008; Kong et al., 2011), whereas there have been few studies on the vertical uneven salt distribution (Bazihizina et al., 2012b; Bingham and Garber, 1970), which was presumably because of difficulties in applying and maintaining the treatments.

The cultivated areas for tomatoes (Solanum lycopersicum L.) have increased significantly across the globe, and greenhouse cultivation has become economically important (He et al., 2007). Tomato is one of the most commonly cultivated crops in saline areas, and it is moderately tolerant of salinity $\left(1.3 \mathrm{dS} \cdot \mathrm{m}^{-1}<\mathrm{EC}\right.$ of the saturated soil extract $<6.0 \mathrm{dS} \cdot \mathrm{m}^{-1}$ ) (Amjad et al., 2014; Cuartero and Fernández-Munoz, 1998; Lu et al., 2010). Several studies have focused on the effects of salt stress on the growth and yield of tomato plants. Above an $\mathrm{EC}$ of $2.5 \mathrm{dS} \cdot \mathrm{m}^{-1}$, a $10 \%$ yield decrease per additional dS. $\mathrm{m}^{-1}$ was obtained (Bazihizina et al., 2012a). As one of the most important physiological disorders of tomato fruit, BER may reduce the marketable yield by up to $50 \%$ and influence the farmer's income (Taylor et al., 2004). Researchers have found that high salinity would increase the incidence of BER (Abdal and Suleiman, 2004; ReinaSanchez et al., 2005), which was generally believed to result from plasma membrane breakdown in response to a low calcium 
concentration in the fruit tissue (Ho and White, 2005). Soil salinity will make negative effects on the fruit $\mathrm{Ca}^{2+}$ absorption and concentration, whereas $\mathrm{Ca}^{2+}$ is essential for proper membrane function (Abdal and Suleiman, 2004; de Freitas et al., 2011; Suzuki et al., 2003). It has also been shown that the $\mathrm{Ca}^{2+}$ accumulation in fruit was significantly connected to the amount of absorbed water and the transpiration of plants (Keiser and Mullen, 1993; Sun et al., 2013). On the other hand, $\mathrm{Na}^{+}$ion toxicity would damage the $\mathrm{Ca}^{2+}$ absorption and utilization systems. Bazihizina et al. (2009) and Flores et al. (2002) found that when plant roots were subjected to an unequal salt distribution, the water absorption of the whole plant was higher than when the roots were subjected to uniform salinity and a compensatory increase in water uptake through the untreated part of the plant was observed. In addition, plant sodium content was usually lower in nonuniform treatments when compared with a uniform soil salt distribution (Bazihizina et al., 2009; Dong et al., 2010). We assumed that the above effects, which were brought on by nonuniform salinity, would promote plant $\mathrm{Ca}^{2+}$ absorption and concentration. To test our hypotheses, the $\mathrm{Ca}^{2+}$ concentration and $\mathrm{Ca}^{2+} / \mathrm{Na}^{+}$absorption of different plant organs were analyzed in this study. Some previous studies focused on the influence of $\mathrm{Na}^{+}$on absorption and the distribution of $\mathrm{Ca}^{2+}$ in the plant organs (Girija et al., 2002). Our former study also discussed the $\mathrm{Na}^{+}$and $\mathrm{Ca}^{2+}$ distribution in the leaves and fruit (Chen et al., 2016). However, when soil salinity was unevenly distributed in a vertical direction, the $\mathrm{Na}^{+}$ and $\mathrm{Ca}^{2+}$ concentrations in different root parts or the movement of $\mathrm{Na}^{+}$and $\mathrm{Ca}^{2+}$ in different plant organs has seldom been reported. According to Pitman (1982) and Zheng et al. (2010), the selective uptake of $\mathrm{Ca}^{2+}$ over $\mathrm{Na}^{+}\left(\mathrm{S}_{\mathrm{Ca} / \mathrm{Na}}\right)$ is a useful indicator for salt stress. To test the possibility in the current study, $\mathrm{S}_{\mathrm{Ca} / \mathrm{Na}}$ values of different organs under different salinity treatments were investigated.

Previous studies indicated that the occurrence of tomato fruit BER was tightly linked with $\mathrm{Ca}^{2+}$ concentration in the fruit tissue (Ho and White, 2005). In addition, more water would be consumed when the plant root zone was under nonuniform salt stress (Bazihizina et al., 2009), and the plant $\mathrm{Ca}^{2+}$ concentration was correlated with the water consumed by plants (Keiser and Mullen, 1993). Thus, we speculated that unequal salt distribution in the soil might influence the amount of absorbed $\mathrm{Ca}^{2+}$ in plants and could decrease BER rates of tomato fruits. However, the relationship between fruit BER and soil salt distribution as well as the amount of $\mathrm{Ca}^{2+}$ absorption by plant root has rarely been studied until now. Previous studies have mostly focused on the relationship between plant growth and heterogeneous salinity in the horizontal direction in the root zone and suggested that the growth of plants might be related to 1) the lowest saline part of the root zone (Bazihizina et al., 2012b), 2) the highest saline part of the root zone (Lycoskoufis et al., 2005), 3) the mean salinity of root zone (Shalhevet, 1994), and 4) the root dry matter weighted mean salinity of the root zone (Minhas and Gupta, 1993). In this study, the correlation between fruit BER and the upper layer salinity, the lower layer salinity, the mean salinity, and the root dry matter weighted mean salinity (RWMS) were investigated. In addition, assuming that selective absorption of $\mathrm{Ca}^{2+}$ over $\mathrm{Na}^{+}$ $\left(\mathrm{S}_{\mathrm{Ca} / \mathrm{Na}}\right)$ might affect the ion concentration and the incidence of fruit BER in tomatoes, the values of root dry matter and selective uptake of $\mathrm{Ca}^{2+}$ over $\mathrm{Na}^{+}$weighted mean salinity (RSWMS) were also be taken into consideration when the relationship between fruit BER and the soil salinity were analyzed.

Based on the theoretical understanding of plant responding to uneven salt stress in the root-zone, we hypothesized that 1) an unequal salt distribution in the vertical direction could promote plant $\mathrm{Ca}^{2+}$ absorption, 2) the selective absorption of $\mathrm{Ca}^{2+}$ over $\mathrm{Na}^{+}\left(\mathrm{S}_{\mathrm{Ca} / \mathrm{Na}}\right)$ could affect the ion concentration and the incidence of BER in tomato fruit.

\section{Materials and Methods}

\section{Growing conditions}

This experiment was conducted from April to June 2014 in a greenhouse located at the Key Laboratory of Efficient Irrigation-Drainage and Agricultural SoilWater Environment in Nanjing, Jiangsu Province, Southern China. The polyethylene pots having a height of $42 \mathrm{~cm}$, upper and lower diameters of 30 and $25 \mathrm{~cm}$, respectively, were used for the experiment. A type of sandy soil with two different salt contents $(0.94 \%$ and $6.22 \%$, respectively) was collected from the coastal area of Dongtai, Jiangsu Province. For the salt distribution in the upper and lower layers, four treatments, i.e., $\mathrm{T}_{1: 1}, \mathrm{~T}_{1: 5}, \mathrm{~T}_{2: 4}$, and $\mathrm{T}_{3: 3}$, which represented the soil salt content of the upper soil layer: lower soil layer at the initiation of treatment were $1 \%: 1 \%, 1 \%: 5 \%, 2 \%: 4 \%$ and $3 \%: 3 \%$, respectively, were used in this study. Peat substrate (GB-Pindstrup Substrate No.1, pH 6.0) was mixed with the original soil at a rate of $32.5 \mathrm{~g}$ per pot to obtain new mixed soil with a bulk density of $0.94 \mathrm{~g} \cdot \mathrm{cm}^{-3}$. In addition, $0.326 \mathrm{~g}$ of urea $(\mathrm{CO}$ $\left.\left(\mathrm{NH}_{2}\right)_{2}\right), 2.5 \mathrm{~g}$ of organic fertilizer $(4 \% \mathrm{~N}, 4 \%$ $\mathrm{P}$, and $4 \% \mathrm{~K}), 0.13 \mathrm{~g}$ of potassium sulfate $\left(\mathrm{K}_{2}\right.$ $\mathrm{SO}_{4}$ ), and $0.38 \mathrm{~g}$ of potassium dihydrogen phosphate $\left(\mathrm{KH}_{2} \mathrm{PO}_{4}\right)$ per pot were mixed with the soil to meet nutrient requirements during the plant growing period. The soil in the pot was divided by a straw layer into upper and lower soil layers with weights of 8.6 and $12.9 \mathrm{~kg}$, respectively. It is noteworthy that the total soil salinity was $T_{1: 5}>T_{2: 4}>$ $\mathrm{T}_{3: 3}$, as we know that uneven salt distribution could relieve the salt stress in the root zone; thus, the soil salinity increase from $\mathrm{T}_{3.3}$ to $\mathrm{T}_{1: 5}$ will bring a negative effect on the uneven salt distribution method. That is to say, if $\mathrm{T}_{1: 5}$ 's plant growth was affected less by salt stress than $\mathrm{T}_{3: 3}$, it means that uneven salt distribution is more effective because of the higher total soil salinity. In this research, we will ignore the difference in total soil salinity between $T_{1: 5}, T_{2: 4}$, and $T_{3: 3}$, and focus on the situation of salt distribution in the soil. The weight, thickness, and depth of the straw layer were $\approx 50 \mathrm{~g}, 3 \mathrm{~cm}$ and $17 \mathrm{~cm}$, respectively. The water-holding capacity $\left(\theta_{\mathrm{f}}\right)$ of the mixed soil was $37 \%$ (Vol.). The pots were spaced at $50 \times 50 \mathrm{~cm}^{2}$. Each treatment contained 12 replications, and four plants were selected randomly when the harvesting experiment was carried out. Tomato (Solanum lycopersicon L. var. Yazhoufenwang) seeds were sown on Mar. 5 when the third true leaf of the seedlings expanded (20 Apr.); seedlings of similar height were selected for transplanting to the pots. Tomato plants were topped by pitching the terminal bud of the main stem when the third flower cluster was visible. Pest and weed controls were conducted according to local commercial practices.

\section{Sampling and analyses}

Water consumption. 5TE probes (Decagon Devices Inc., Pullman, WA) were connected to an EM50 data logger (Decagon Devices Inc.) and buried at the center of the upper and lower soil layers, which were chosen for continuously monitoring volumetric soil water content $\left(\theta_{\mathrm{v}}\right)$. Water consumption was calculated from $\theta_{\mathrm{v}}$, and the volume of the soil. $\theta_{\mathrm{v}}$ was kept around $50 \%$ of the water-holding capacity $\left(\theta_{\mathrm{f}}\right)$ from transplanting to $26 \mathrm{~d}$ after transplanting (DAT). From 27 DAT to the end of the experiment, the lower and upper limit of $\theta_{\mathrm{v}}$ in each pot was set to $60 \%$ of $\theta_{\mathrm{f}}$ and $80 \%$ of $\theta_{\mathrm{f}}$, respectively.

Fruit BER. Tomato plants were harvested on June 15. The number and fresh weight of normal or BER fruit were measured from four samples of each treatment, respectively. Incidence of BER and BER fruit fresh yield (BER FY) percentage were calculated as:

$$
\begin{gathered}
\text { Incidence of BER }=\frac{n_{1}}{n_{1}+n_{2}} \\
\text { BER FY percentage }=\frac{y_{1}}{y_{1}+y_{2}}
\end{gathered}
$$

where, $n_{1}$ and $y_{1}$ represents the number and fresh weight of BER fruit, respectively, and $n_{2}$ and $y_{2}$ represents the number and the fresh weight of non-BER fruit, respectively.

Dry biomass of plant organs. After washing carefully with tap water, root systems in upper and lower soil layers were collected, and the aboveground part was also separated into stems, leaves, and fruits. Dry biomass of plant samples was determined after oven drying the samples at $70{ }^{\circ} \mathrm{C}$ until they reached a constant weight.

$\mathrm{Na}^{+}$and $\mathrm{Ca}^{2+}$ concentrations in organs and soil. After drying the samples, organs 
Table 1. Root dry matter and water consumption in the upper soil layer, lower soil layer, and whole soil layer for tomato plants subjected to $\mathrm{T}_{1: 1}, \mathrm{~T}_{1: 5} ; \mathrm{T}_{2: 4}$, and $\mathrm{T}_{3: 3}$ treatments.

\begin{tabular}{|c|c|c|c|c|c|c|}
\hline \multirow[b]{2}{*}{ Treatment } & \multicolumn{2}{|c|}{ Upper soil layer } & \multicolumn{2}{|c|}{ Lower soil layer } & \multicolumn{2}{|c|}{ Whole soil layer } \\
\hline & $\overline{\text { Root dry matter }(\mathrm{g})}$ & Water consumption $(\mathrm{L})$ & $\overline{\text { Root dry matter }(\mathrm{g})}$ & Water consumption $(\mathrm{L})$ & $\overline{\text { Root dry matter (g) }}$ & Water consumption $(\mathrm{L})$ \\
\hline $\mathrm{T}_{1.5}$ & $6.93 \pm 1.30 \mathrm{a}$ & $25.18 \pm 0.33 \mathrm{a}$ & $1.65 \pm 0.41 b$ & $8.44 \pm 0.12 \mathrm{c}$ & $8.57 \pm 1.49 \mathrm{ab}$ & $33.62 \pm 0.23 \mathrm{a}$ \\
\hline $\mathrm{T}_{2 \cdot 4}$ & $7.44 \pm 1.20 \mathrm{a}$ & $16.11 \pm 0.18 \mathrm{c}$ & $2.64 \pm 0.55 b$ & $7.86 \pm 0.24 \mathrm{~d}$ & $10.08 \pm 1.73 \mathrm{a}$ & $23.97 \pm 0.34 \mathrm{~b}$ \\
\hline
\end{tabular}

The treatment symbols $\mathrm{T}_{1: 1}, \mathrm{~T}_{1: 5}, \mathrm{~T}_{2: 4}$, and $\mathrm{T}_{3 \cdot 3}$ represent the soil salt content of the upper and lower layers at the initiation of the treatment, which were $1 \%$ and $1 \%, 1 \%$ and $5 \%, 2 \%$ and $4 \%$, and $3 \%$ and $3 \%$, respectively. The data are mean $\pm \mathrm{SD}(n=4)$. Values followed by different superscript letters within a row are significantly different at $5 \%$ according to Duncan's multiple range tests, whereas the lowercase letters indicate $P<0.05$, and uppercase letters indicate a $P<0.01$.
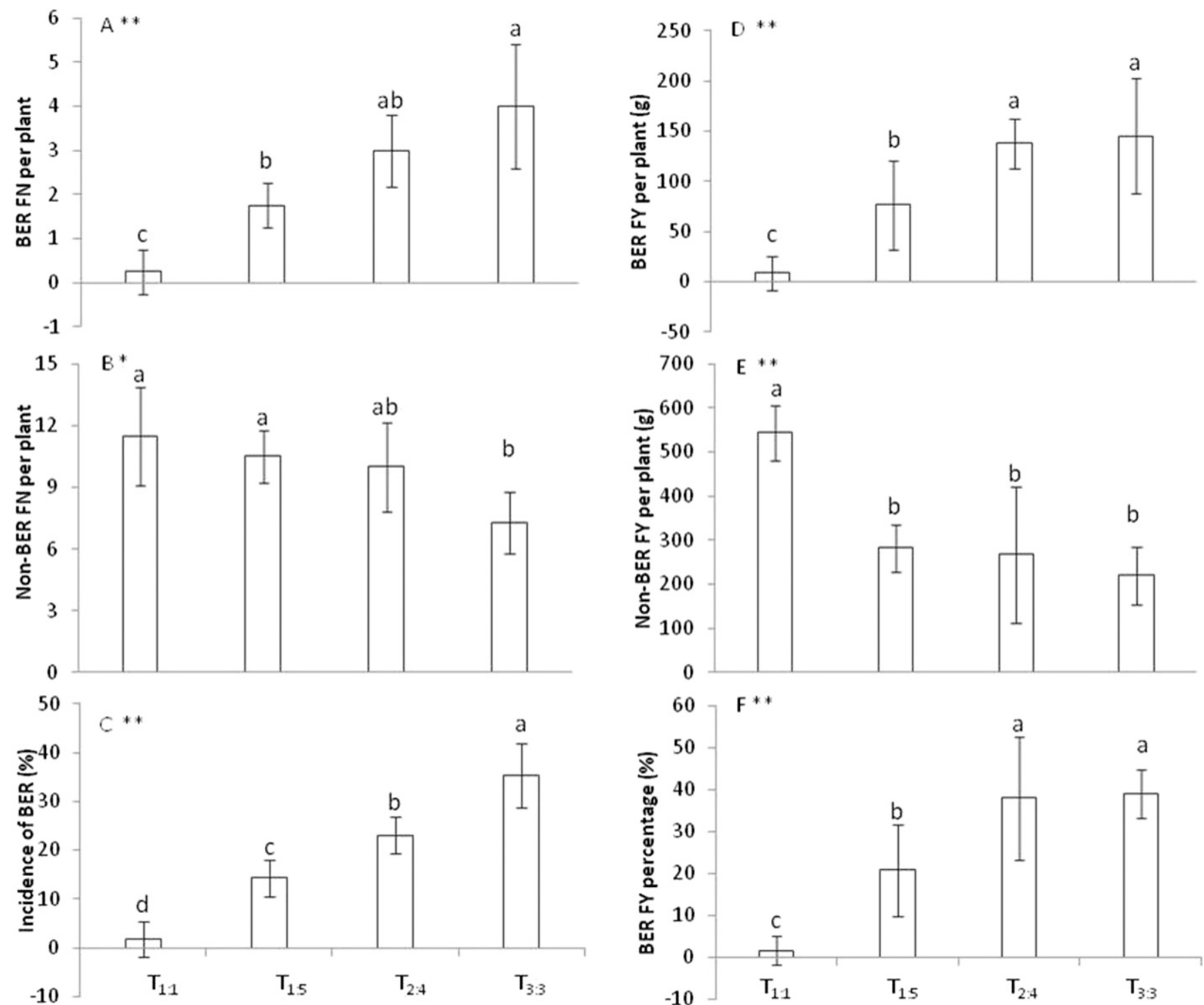

Fig. 1. (A) Number of blossom-end rot (BER) fruit per plant, (B) number of non-BER fruit per plant, (C) incidence of BER, (D) BER fruit fresh yield (BER FY) per plant, (E) non-BER FY, and (F) BER FY percentage under different treatments. The treatment symbols $\mathrm{T}_{1: 1}, \mathrm{~T}_{1: 5}, \mathrm{~T}_{2: 4}$, and $\mathrm{T}_{3: 3}$ represent the soil salt contents of the upper and lower layers at the initiation of the treatment, which were $1 \%$ and $1 \%, 1 \%$ and $5 \%, 2 \%$ and $4 \%$, and $3 \%$ and $3 \%$, respectively. Each value is the Mean $\pm \mathrm{SD}(n=4)$. The different letters on the tops of column for the same soil layer indicate significant differences between treatments at $5 \%$ $(*)$ or $(* *)$ according to Duncan's multiple range test.

were grinded to pass through a $2-\mathrm{mm}$ sieve. After $1 \mathrm{~g}$ of dried samples was digested with nitric acid and perchloric acid, the solution was diluted with deionized water to $100 \mathrm{~mL}$. Soil samples were taken from the gap of the root, after air-drying the samples, soil was grinded to pass through a $1-\mathrm{mm}$ sieve, and $2 \mathrm{~g}$ of soil were mixed with $10 \mathrm{~mL}$ of demonized water. $\mathrm{Na}^{+}$and $\mathrm{Ca}^{2+}$ concentrations in organs and soil were measured using inductively coupled plasma optical emission spectrometry (ICP-OES, 710 Series; Agilent Technologies).

Selective uptake of $\mathrm{Ca}^{2+}$ over $\mathrm{Na}^{+}$. According to Pitman (1982), the selective uptake of $\mathrm{Ca}^{2+}$ over $\mathrm{Na}^{+}$in the upper roots, lower roots, stem, fruits, and leaves was calculated as 


$$
S_{\mathrm{Ca} / \mathrm{Na} \text { (upper-root) }}=\frac{\mathrm{Ca}_{\text {upper-root }} / \mathrm{Na}_{\text {upper-root }}}{\mathrm{Ca}_{\text {upper-soil }} / \mathrm{Na}_{\text {upper-soil }}}
$$

$$
S_{\mathrm{Ca} / \mathrm{Na} \text { (lower-root) }}=\frac{\mathrm{Ca}_{\text {lower-root }} / \mathrm{Na}_{\text {lower-root }}}{\mathrm{Ca}_{\text {lower-soil }} / \mathrm{Na}_{\text {lower-soil }}}
$$

$$
\begin{gathered}
S_{\mathrm{Ca} / \mathrm{Na} \text { (stem) }}=\frac{\mathrm{Ca}_{\text {stem }} / \mathrm{Na}_{\text {stem }}}{\mathrm{Ca}_{\text {upper-root }} / \mathrm{Na}_{\text {upper-root }}} \\
S_{\mathrm{Ca} / \mathrm{Na} \text { (fruit) }}=\frac{\mathrm{Ca}_{\text {fruit }} / \mathrm{Na}_{\text {fruit }}}{\mathrm{Ca}_{\text {stem }} / \mathrm{Na}_{\text {stem }}} \\
S_{\mathrm{Ca} / \mathrm{Na} \text { (leaf) }}=\frac{\mathrm{Ca}_{\text {leaf }} / \mathrm{Na}_{\text {leaf }}}{\mathrm{Ca}_{\text {stem }} / \mathrm{Na}_{\text {stem }}}
\end{gathered}
$$

where $\mathrm{Ca}_{\text {upper-soil }}, \mathrm{Ca}_{\text {lower-soil }}, \mathrm{Ca}_{\text {upper-root }}$, $\mathrm{Ca}_{\text {lower-root }}, \mathrm{Ca}_{\text {stem }}, \mathrm{Ca}_{\text {fruit }}$, and $\mathrm{Ca}_{\text {leaf }}$ represent the $\mathrm{Ca}^{2+}$ concentrations of the upper layer soil, lower soil layer, upper roots, lower roots, stems, fruits, and leaves, respectively; $\mathrm{Na}_{\text {upper-soil }}, \quad \mathrm{Na}_{\text {lower-soil }}, \quad \mathrm{Na}_{\text {upper-root }}$, $\mathrm{Na}_{\text {lower-root }}, \mathrm{Na}_{\text {stem }}, \mathrm{Na}_{\text {fruit }}$, and $\mathrm{Na}_{\text {leaf }}$ represents the $\mathrm{Na}^{+}$concentrations of the upper layer soil, lower soil layer, upper roots, lower roots, stems, fruits, and leaves, respectively.

Different formats to represent heterogeneous salinity in the root zone. Surface salinity and the highest salinity (HS) were the upper and lower layer soil salt content, respectively. Arithmetic mean salinity (AMS) was calculated as the average of the upper and lower soil salt content. Refer to Minhas and Gupta (1993), RWMS was calculated as:

$$
\mathrm{RWMS}=\frac{r_{1} \times s_{1}+r_{2} \times s_{2}}{r_{1}+r_{2}}
$$

\section{RSWMS}

$$
\begin{aligned}
& \text { RSWMS } \\
& =\frac{r_{1} \times S_{\mathrm{Ca} / \mathrm{Na}}^{1} \times s_{1}+r_{2} \times S_{\mathrm{Ca} / \mathrm{Na}}^{2} \times s_{2}}{r_{1} \times S_{\mathrm{Ca} / \mathrm{Na}}^{1}+r_{2} \times S_{\mathrm{Ca} / \mathrm{Na}}^{2}}
\end{aligned}
$$

where $r_{1}$ and $r_{2}$ are the dry weights of the upper and lower roots, respectively, $S_{\mathrm{Ca} / \mathrm{Na}}^{1} S_{\mathrm{Ca} / \mathrm{Na}}^{2}$ is the selective uptake of $\mathrm{Ca}^{2+}$ over $\mathrm{Na}^{+}$from the soil in upper and lower roots, respectively, and $s_{1}$ and $s_{2}$ are the salt contents of the upper and lower soil layers, respectively.

\section{Statistical analysis}

One-way analysis of variance was performed using the general linear modelunivariate procedure with SPSS 13.0 software (SPSS, Chicago, IL). The mean values of each treatment were compared using Duncan's multiple range test when significant differences were detected. When appropriate, the Student's $t$ test was applied to compare treatment means. The significant level was $P<0.05$. Linear regression was also carried out in SPSS.

\section{Results}

As shown in Table 1, when compared with $\mathrm{T}_{3: 3}(4.82 \mathrm{~g})$, the upper-root dry matter of $\mathrm{T}_{1.5}(6.93 \mathrm{~g})$ and $\mathrm{T}_{2 \cdot 4}(7.44 \mathrm{~g})$ was significantly higher. For the root dry matter of the lower layer, no difference was found between $T_{1: 5}, T_{2: 4}$, and $T_{3: 3}$, whereas all of them were significantly lower compared with $\mathrm{T}_{1: 1}$. Water consumption of the upper soil layer significantly decreased from $25.18 \mathrm{~L}$ $\left(\mathrm{T}_{1: 5}\right)$ to $18.58 \mathrm{~L}\left(\mathrm{~T}_{1: 1}\right), 16.11 \mathrm{~L}\left(\mathrm{~T}_{2: 4}\right)$, and $12.38 \mathrm{~L}\left(\mathrm{~T}_{3: 3}\right)$, respectively. The water consumption of the lower layer in $\mathrm{T}_{1: 1}$ was 15.39 $\mathrm{L}$, which was significantly higher compared with the other three treatments. When considering the whole root zone, $\mathrm{T}_{1: 1}$ and $\mathrm{T}_{1: 5}$ consumed significantly more water compared with $\mathrm{T}_{2: 4}$ and $\mathrm{T}_{3: 3}$.

BER fruit number (A), non-BER fruit number (B), incidence of BER (C), BER fresh yield (D), non-BER fresh yield (E), and BER FY percentage $(\mathrm{F})$ are shown in Fig. 1. When soil salt was equally distributed, with an increase in the average salt concentration in the whole soil profile, the average number and fresh yield of BER fruit dramatically increased from 0.25 and $8.42 \mathrm{~g}$ of $\mathrm{T}_{1: 1}$ to 4.00 and $145.40 \mathrm{~g}$ of $\mathrm{T}_{3: 3}$. Similarly, the incidence of BER and BER FY percentage significantly increased from $1.79 \%$ and $1.70 \%$ of $\mathrm{T}_{1: 1}$ to $35.24 \%$ and $39.12 \%$ of $\mathrm{T}_{3: 3}$, respectively. As shown in Fig. 1, the incidence of BER and BER FY percentage of
$\mathrm{T}_{1: 5}$ was $14.24 \%$ and $20.91 \%$, respectively, and those percentages were significantly lower as compared with $\mathrm{T}_{3: 3}$.

$\mathrm{Na}^{+}$and $\mathrm{Ca}^{2+}$ concentrations in different plant organs are shown in Fig. 2. The increase in salinity had a significant effect on plant $\mathrm{Na}^{+}$concentration. When soil salt increased from $1 \%$ of $\mathrm{T}_{1: 1}$ to $3 \%$ of $\mathrm{T}_{3: 3}$ on an average, the $\mathrm{Na}^{+}$concentrations in the stems, leaves, and fruits significantly increased from 0.108 , 0.234 , and $0.058 \mathrm{~mm}$ to $0.540,1.308$, and $0.168 \mathrm{~mm}$, respectively. When the average salt content in the whole soil layer was similar, the $\mathrm{Na}^{+}$concentration in the aboveground parts decreased as the soil salt distribution diversity increased. The $\mathrm{Na}^{+}$concentrations in stems, leaves, and fruits for $\mathrm{T}_{1: 5}$ were $39 \%$, $65 \%$, and $69 \%$ of $\mathrm{T}_{2: 4}$, and $31 \%, 54 \%$, and $58 \%$ of $\mathrm{T}_{3: 3}$, respectively, and the differences were significant. In addition, the unequal salt distribution had a significant effect on fruit $\mathrm{Ca}^{2+}$ concentration with a $47.6 \%$ higher in $\mathrm{T}_{1.5}$ than $\mathrm{T}_{3: 3}$. The upper root $\mathrm{Ca}^{2+}$ concentration of $\mathrm{T}_{1: 1}$ and $\mathrm{T}_{1: 5}$ was higher compared with $\mathrm{T}_{2: 4}$ and $T_{3: 3}$, whereas the lower roots of $T_{1: 5}$ showed the lowest amounts among the treatments.

The correlation between $\mathrm{Ca}^{2+}$ and $\mathrm{Na}^{+}$ concentrations and incidence of BER were analyzed when the data from four different treatments were pooled in this experiment
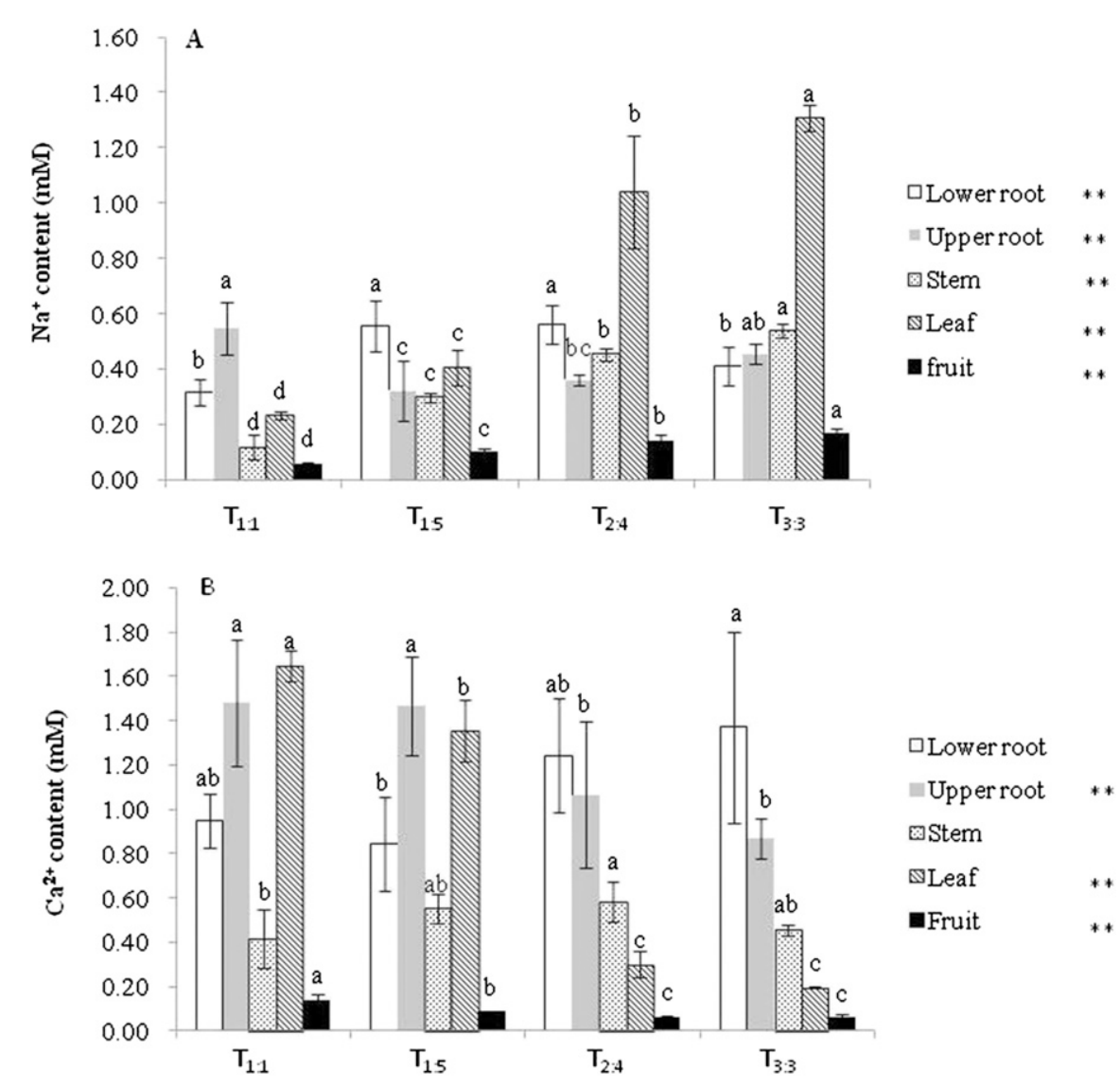

Fig. 2. (A) $\mathrm{Na}^{+}$and (B) $\mathrm{Ca}^{2+}$ concentration in plant leaves, stems, fruits, upper-part roots, and lower-part roots of $\mathrm{T}_{1: 1}, \mathrm{~T}_{1: 5}, \mathrm{~T}_{2: 4}$, and $\mathrm{T}_{3: 3}$. The treatment symbols $\mathrm{T}_{1: 1}, \mathrm{~T}_{1: 5}, \mathrm{~T}_{2: 4}$, and $\mathrm{T}_{3: 3}$ represent the soil salt contents of the upper and lower layers at the initiation of the treatment, which were $1 \%$ and $1 \%, 1 \%$ and $5 \%, 2 \%$ and $4 \%$, and $3 \%$ and $3 \%$, respectively. Each value is the Mean $\pm \operatorname{SD}(n=4)$. The different letters on the tops of the column for the same soil layer indicate significant differences in the same organ between treatments at $5 \%(*)$ or $1 \%(* *)$ according to Duncan's multiple range test. 
(Fig. 3). A significant negative relationship was found between the $\mathrm{Ca}^{2+}$ concentration and the incidence of BER $(P<0.05)$. In addition, positive linear relationships between the incidence of BER and $\mathrm{Na}^{+}$concen-
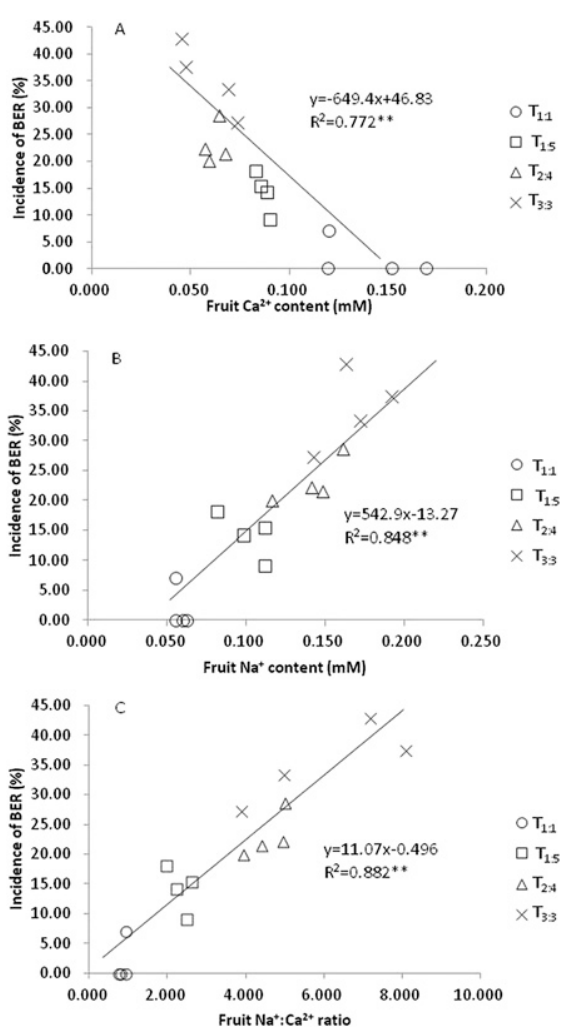

Fig. 3. The correction between incidence of blossomend rot (BER) and fruit $\mathrm{Ca}^{2+}$ concentration, $\mathrm{Na}^{+}$ concentration, and $\mathrm{Na}^{+} / \mathrm{Ca}^{2+}$ ratio. The analysis was based on 16 plants that belonged to $T_{1: 1}, T_{1: 5}$, $\mathrm{T}_{2: 4}$, and $\mathrm{T}_{3: 3}$. The treatment symbols $\mathrm{T}_{1: 1}, \mathrm{~T}_{1: 5}$, $\mathrm{T}_{2: 4}$, and $\mathrm{T}_{3: 3}$ represent the soil salt contents of the upper and lower layers at the initiation of the treatment, which were $1 \%$ and $1 \%, 1 \%$ and $5 \%$, $2 \%$ and $4 \%$, and $3 \%$ and $3 \%$, respectively. Equation and correlation coefficients of the three relationships are shown in this figure. *Significance at $P<0.05$ and $* *$ significance at $P<0.01$. tration and the $\mathrm{Na}^{+} / \mathrm{Ca}^{2+}$ ratio were also found $(P<0.01)$.

As shown in Table 2, the $\mathrm{Ca}^{2+} / \mathrm{Na}^{+}$of $\mathrm{T}_{1: 5}$ in the upper root was the highest among the treatments, whereas the lower root parts showed the opposite trend. The $\mathrm{Ca}^{2+} / \mathrm{Na}^{+}$of the aboveground biomass decreased with the increase in average soil salinity, where the $\mathrm{Ca}^{2+} / \mathrm{Na}^{+}$of stems, leaves, and fruits of $\mathrm{T}_{1: 1}$ showed the highest values among the treatments. When the average salt content in the soil profile was similar, unequal salt distribution for treatment $T_{1: 5}$ led to a significantly higher $\mathrm{Ca}^{2+} / \mathrm{Na}^{+}$in stems, leaves, and fruits when compared with $\mathrm{T}_{2: 4}$ and $\mathrm{T}_{3: 3}$.

As shown in Table 3, selective uptake of $\mathrm{Ca}^{2+}$ over $\mathrm{Na}^{+}\left(\mathrm{S}_{\mathrm{Ca} / \mathrm{Na}}\right)$ in the upper roots of $\mathrm{T}_{1: 5}$ was $82.7 \%, 72.0 \%$, and $166.1 \%$ more than $\mathrm{T}_{1: 1}, \mathrm{~T}_{2: 4}$, and $\mathrm{T}_{3: 3}$, respectively, which suggested that the upper-root system of $\mathrm{T}_{1: 5}$ suffered less salt stress compared with the other treatments. The opposite trend was observed in the lower-root system and $S_{\mathrm{Ca} / \mathrm{Na} \text { (lower root) }}$ of $\mathrm{T}_{1: 5}$ significantly decreased to 42.76, whereas the values for $\mathrm{T}_{1: 1}, \mathrm{~T}_{2: 4}$, and $\mathrm{T}_{3: 3}$ were $85.56,62.70$, and 91.52, respectively.

As shown in Fig. 4, the correlation between incidence of BER and SS, RWMS, RSWMS was significant, and the highest correlation coefficient was found in RSWMS $\left(R^{2}=0.91\right)$. In addition, there was no significant relationship between the incidence of BER and AMS or the HS.

\section{Discussion}

Increased salinity will promote the occurrence of fruit BER (Van Ieperen, 1996). Reina-Sanchez et al. (2005) found the average number of BER fruits in four tomato cultivars increased with salinity changing from $2 \%$ in $0 \mathrm{~mm} \mathrm{Na}^{+}$conditions to $16 \%$ in $75 \mathrm{mM}$. In our study, under a homogeneous distribution of salt in the vertical direction of the root zone, the incidence of BER and the BER FY percentage of $\mathrm{T}_{3: 3}$ (soil salinity was $3 \%$ ) were $35.3 \%$ and $39.1 \%$, respectively, and those values were significantly higher than that of $\mathrm{T}_{1: 1}$ (soil salinity was $1 \%$, Fig. 1).
While under a similar salt concentration throughout the entire soil profile and with an increased salt concentration in the upper soil profile, the incidence of BER for $\mathrm{T}_{3: 3}$ was $147 \%$ and $53 \%$ higher as compared with $T_{1: 5}$ and $\mathrm{T}_{2: 4}$. It is generally believed that fruit BER is linked to a deficiency of $\mathrm{Ca}^{2+}$ concentration in fruit tissue (Ho and White, 2005), especially in the distal end of the fruit (Ho et al., 1995). In the current study, when average soil salinity increased from $1 \%$ $\left(\mathrm{T}_{1: 1}\right)$ to $3 \%\left(\mathrm{~T}_{1: 5}, \mathrm{~T}_{2: 4}\right.$ and $\left.\mathrm{T}_{3: 3}\right)$, the fruit $\mathrm{Ca}^{2+}$ concentration significantly decreased from $0.140 \mathrm{~mm}$ to $0.086,0.062$, and $0.058 \mathrm{~mm}$, respectively (Fig. 2). In addition, an uneven salt distribution in the vertical direction had a significant effect on fruit $\mathrm{Ca}^{2+}$ concentration with a $40.6 \%$ increase in $\mathrm{T}_{1.5}$ compared with $\mathrm{T}_{3: 3}$ (Fig. 1). Fruit $\mathrm{Ca}^{2+}$ in different treatments showed the opposite trend compared with the incidence of BER, and significant negative linear relationships between them were observed $\left(R^{2}=0.77\right.$, Fig. 3). Morard et al. (2000) proposed that $\mathrm{Ca}^{2+}$ uptake and movement in the plant was tightly linked with water consumption and transpiration. The increase in salinity had a significant effect on water consumption in this study. Under uniform distribution of salt in the root zone, $\mathrm{T}_{1: 1}$ consumed $48.1 \%$ more water when compared with $\mathrm{T}_{3: 3}$ (Table 1). There was a similar concentration in the whole root profile, and tomato water consumption was also significantly affected by a vertical distribution of salt in the root zone. As shown in Table 1, water consumption decreased with the increasing salt concentration in the upper soil profile $\left(\mathrm{T}_{2: 4}\right.$ and $\mathrm{T}_{3: 3}$ compared with $\mathrm{T}_{1: 5}$ ). When soil salinity was distributed unevenly in the vertical direction, seldom former researchers focused on the water consumption in different root part, but when soil salinity was uneven distributed in the horizontal direction, Bazihizina et al. (2009) and Flores et al. (2002) pointed out that the main reason for the plant to consume more water in the uneven salt distribution environment might be a compensatory increase in water uptake through the salt-free

Table 2. $\mathrm{Ca}^{2+} / \mathrm{Na}^{+}$ratio of the upper root layer, lower root layer, stems, leaves, and fruits in $\mathrm{T}_{1: 1}, \mathrm{~T}_{1: 5}, \mathrm{~T}_{2: 4}$, and $\mathrm{T}_{3: 3}$.

\begin{tabular}{lccccc}
\hline Treatment & Upper root $\mathrm{Ca}^{2+} / \mathrm{Na}^{+}$ratio & Lower root $\mathrm{Ca}^{2+} / \mathrm{Na}^{+}$ratio & Stem $\mathrm{Ca}^{2+} / \mathrm{Na}^{+}$ratio & $\mathrm{Leaf} \mathrm{Ca}^{2+} / \mathrm{Na}^{+} \mathrm{ratio}$ & $\mathrm{Fruit}^{2+} \mathrm{Ca}^{2+} / \mathrm{Na}^{+}$ratio \\
\hline $\mathrm{T}_{1: 1}$ & $4.89 \pm 1.60 \mathrm{~b}$ & $5.35 \pm 1.35 \mathrm{ab}$ & $6.22 \pm 0.81 \mathrm{a}$ & $12.33 \pm 0.77 \mathrm{a}$ \\
$\mathrm{T}_{1: 5}$ & $8.93 \pm 4.05 \mathrm{a}$ & $2.67 \pm 0.64 \mathrm{~b}$ & $3.22 \pm 0.23 \mathrm{~b}$ & $5.90 \pm 0.81 \mathrm{~b}$ & $1.53 \pm 0.48 \mathrm{a}$ \\
$\mathrm{T}_{2: 4}$ & $5.19 \pm 1.91 \mathrm{~b}$ & $3.92 \pm 1.15 \mathrm{bc}$ & $2.25 \pm 0.42 \mathrm{c}$ & $0.52 \pm 0.17 \mathrm{c}$ & $0.77 \pm 0.13 \mathrm{c}$ \\
$\mathrm{T}_{3: 3}$ & $3.36 \pm 0.62 \mathrm{~b}$ & $5.72 \pm 0.96 \mathrm{a}$ & $1.47 \pm 0.02 \mathrm{~d}$ & $0.26 \pm 0.01 \mathrm{c}$ & $0.63 \pm 0.20 \mathrm{c}$ \\
\hline
\end{tabular}

The treatment symbols $\mathrm{T}_{1: 1}, \mathrm{~T}_{1: 5}, \mathrm{~T}_{2: 4}$, and $\mathrm{T}_{3: 3}$ represent the soil salt contents of the upper and lower layers at the initiation of the treatment, which were $1 \%$ and $1 \%, 1 \%$ and $5 \%, 2 \%$ and $4 \%$, and $3 \%$ and $3 \%$, respectively. Data are the mean \pm SD $(n=4)$. Values followed by different superscript letters within a row are significantly different at $5 \%$ according to Duncan's multiple range tests, whereas the lowercase letters mean $P<0.05$ and uppercase letters mean $P<0.01$.

Table 3. Upper and lower root, stem, leaf, and fruit $\mathrm{Ca}^{2+} / \mathrm{Na}^{+}$selectively absorption.

\begin{tabular}{|c|c|c|c|c|c|}
\hline Treatment & $\mathrm{S}_{\mathrm{Ca} / \mathrm{Na} \text { (upper-root) }}$ & $\mathrm{S}_{\mathrm{Ca} / \mathrm{Na} \text { (lower root) }}$ & $\mathrm{S}_{\mathrm{Ca} / \mathrm{Na}(\mathrm{stem})}$ & $\mathrm{S}_{\mathrm{Ca} / \mathrm{Na} \text { (leaf) }}$ & $\overline{\mathrm{S}_{\mathrm{Ca} / \mathrm{Na} \text { (fruit) }}}$ \\
\hline $\mathrm{T}_{1: 1}$ & $78.23 \pm 25.52 b$ & $85.56 \pm 21.56 \mathrm{ab}$ & $1.42 \pm 0.64 \mathrm{a}$ & $2.00 \pm 0.18 \mathrm{a}$ & $0.68 \pm 0.11 \mathrm{a}$ \\
\hline $\mathrm{T}_{2: 4}$ & $83.11 \pm 30.60 b$ & $62.70 \pm 18.36 \mathrm{bc}$ & $0.47 \pm 0.17 b$ & $0.25 \pm 0.10 \mathrm{~b}$ & $0.35 \pm 0.09 \mathrm{~b}$ \\
\hline $\mathrm{T}_{3: 3}$ & $53.73 \pm 9.97 b$ & $91.52 \pm 15.35 \mathrm{a}$ & $0.45 \pm 0.07 \mathrm{~b}$ & $0.18 \pm 0.01 \mathrm{~b}$ & $0.43 \pm 0.14 \mathrm{~b}$ \\
\hline
\end{tabular}

The treatment symbols $\mathrm{T}_{1: 1}, \mathrm{~T}_{1: 5}, \mathrm{~T}_{2: 4}$, and $\mathrm{T}_{3: 3}$ represent the soil salt contents of the upper and lower layers at the initiation of the treatment, which were $1 \%$ and $1 \%, 1 \%$ and $5 \%, 2 \%$ and $4 \%$, and $3 \%$ and $3 \%$, respectively. Data are the mean \pm SD $(n=4)$. Values followed by different superscript letters within a row are significantly different at $5 \%$ according to Duncan's multiple range tests, whereas lowercase letters mean $P<0.05$ and upper-case letters mean $P<0.01$. 

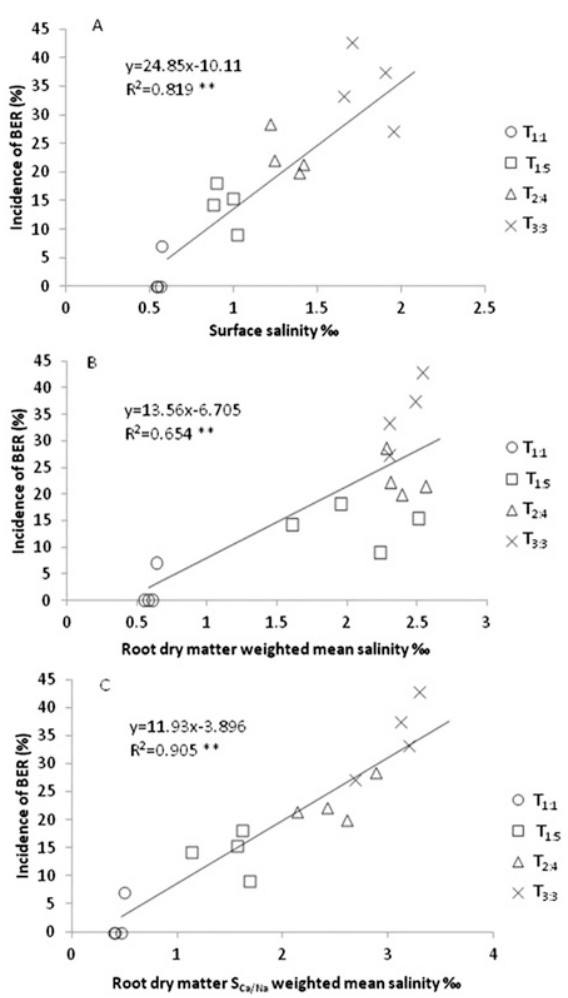

Fig. 4. The relationship between the incidence of blossom-end rot (BER) with the upper layer salinity (US), root dry matter weighted mean salinity (RWMS), root dry matter and $\mathrm{S}_{\mathrm{Ca} / \mathrm{Na}}$ weighted mean salinity (RSWMS) as well as the formulas between them, from $\mathrm{A}$ to $\mathrm{C}$, are shown. The incidence of BER for different treatments tested an average number of four plants that belonged to the same treatment. **Significance of lines at $P<0.01$.

part when the other root system experienced to salinity. Thus, we believe that there may be similar compensatory mechanism for water absorption in horizontal and vertical nonuniform salinity. The water consumption in the upper layer of $T_{1: 5}$ was $103.3 \%$ higher than the upper layer of $T_{3: 3}$ (Table 1).

It is noteworthy that in this research a better indicator for the incidence of BER was $\mathrm{Na}^{+} / \mathrm{Ca}^{2+}$ in the fruit $\left(\mathrm{R}^{2}=0.88, P<\right.$ 0.01 ), and it proved to be more effective than $\mathrm{Ca}^{2+}$ alone $\left(R^{2}=0.77\right.$, Fig. 3). Negative effects induced by $\mathrm{Na}^{+}$on $\mathrm{Ca}^{2+}$ uptake systems have long been recognized (Demidchik and Maathuis, 2007; Ebrahimi and Bhatla, 2012; Hilge, 2012). In this study, as shown in Fig. 2, $\mathrm{Ca}^{2+}$ decreased with the increase in the $\mathrm{Na}^{+}$concentration in the fruit, and there was a significant negative correlation between fruit $\mathrm{Na}^{+}$and $\mathrm{Ca}^{2+}$ concentration. Under the uniform distribution of salt in the root zone, with the increased salt concentration, the fruit $\mathrm{Na}^{+}$concentration increased from $0.058 \mathrm{~mm}$ in $\mathrm{T}_{1: 1}$ to $0.164 \mathrm{~mm}$ in $\mathrm{T}_{3: 3}$, whereas a $58.0 \%$ decrease was found in the fruit $\mathrm{Ca}^{2+}$ concentration. Under the similar salt concentration in the whole soil profile, soil salt distribution also had a significant effect on the $\mathrm{Na}^{+}$and $\mathrm{Ca}^{2+}$ concentration in the fruit when the soil salt content of the upper soil profile increased from $1 \%\left(\mathrm{~T}_{1: 5}\right.$, nonuniform distribution of salt in the root zone) to $3 \%\left(\mathrm{~T}_{3: 3}\right.$, uniform distribution of salt in the root zone). There was a $65.8 \%$ increase in the $\mathrm{Na}^{+}$concentration as well as a $32.2 \%$ reduction in the $\mathrm{Ca}^{2+}$ concentration in tomato fruits.

The selective uptake of $\mathrm{Ca}^{2+}$ over $\mathrm{Na}^{+}$ $\left(\mathrm{S}_{\mathrm{Ca} / \mathrm{Na}}\right)$ of the upper roots, lower roots, stems, leaves, and fruit is shown in Table 3. $\mathrm{S}_{\mathrm{Ca} / \mathrm{Na}}$ of the upper roots for $\mathrm{T}_{1: 5}$ were significantly higher compared with $\mathrm{T}_{3: 3}$, whereas a significantly lower value of $T_{1: 5}$ compared with $\mathrm{T}_{3: 3}$ were observed in the lower root parts. As shown in Table $3, \mathrm{~S}_{\mathrm{Ca} / \mathrm{Na}}$ decreased with the increase in salt content in the soil, and similar results were found by Pitman (1982) and Zheng et al. (2010). Interestingly, it was observed that the upper root $\mathrm{S}_{\mathrm{Ca} / \mathrm{Na}}$ for $\mathrm{T}_{1: 5}$ were 1.83 times higher than $\mathrm{T}_{1: 1}$, even though both soil layers contained a similar salt concentration. This phenomenon could be partially explained by the higher water consumption in the upper soil layer of $\mathrm{T}_{1: 5}$ compared with $\mathrm{T}_{1: 1}$ (Table 1 ) because $\mathrm{Ca}^{2+}$ uptake was tightly linked with water movement (Keiser and Mullen, 1993). On the other hand, we also speculated that the difference between $\mathrm{S}_{\mathrm{Ca} / \mathrm{Na} \text { (upper root) }}$ of $\mathrm{T}_{1: 1}$ and $T_{1: 5}$ might be related to some internal mechanism, and this speculation needs to be further investigated in the future study.

A significant correlation was observed between fruit incidence of BER and SS in Fig. 4A $\left(R^{2}=0.82, P<0.01\right)$, and a similar result was obtained by Bernstein and Francois (1973), who indicated that the surface soil salinity was the key factor driving water consumption by the plants. On the other hand, Minhas and Gupta (1993) held the opinion that plant growth was affected by RWMS of the soil. Similarly, in the current study, it was inferred that the relationship between incidence of BER and RSWMS was also significant $\left(R^{2}=0.654, P<0.01\right)$. Interestingly, the relationship between the incidence of fruit BER and RSWMS was closer than the other soil salinity indicators (Fig. $4, R^{2}=0.91, P<0.01$ ), which indicated that the RSWMS might be a good indicator to represent the salinity stress degree in the root zone. A significant decrease in RSWMS was also concluded when soil salinity changed from even distribution $\left(\mathrm{T}_{3: 3}\right)$ to uneven distribution $\left(\mathrm{T}_{1: 5}\right.$, Fig. $\left.4, \mathrm{P}<0.01\right)$, which represents that the uneven salt distribution could relieve the salt stress by promote root growth and selective uptake of $\mathrm{Ca}^{2+}$ over $\mathrm{Na}^{+}$, and then decreases the incidence of tomato fruit BER. Based on the results of this research, we believe that an uneven salt distribution in the vertical direction could prevent tomato fruit from BER, and increase the economic yield and also the farmer's income.

\section{Conclusion}

In summary, the present study demonstrated that increased soil salinity in the root zone would lead to high incidence of fruit BER, but if soil salinity was unevenly distributed in the vertical direction $\left(\mathrm{T}_{1: 5}\right)$, the occurrence of BER decreased. When soil salinity was unevenly distributed in the vertical direction, the upper-root system selectively absorbed more $\mathrm{Ca}^{2+}$ instead of $\mathrm{Na}^{+}$, which was the key factor underlying the high $\mathrm{Ca}^{2+} / \mathrm{Na}^{+}$ratio in fruit, and that high ratio consequently resulted in a lower incidence of BER. In addition, the RSWMS might be the best indicator for fruit BER incidence.

\section{Literature Cited}

Abdal, M. and M. Suleiman. 2004. Blossom end rot occurrence in calcareous soil of Kuwait. First Intl. Symp. Tomato Dis. 695: 63-66.

Amjad, M., J. Akhtar, M. Anwar-ul-Haq, A. Yang, S.S. Akhtar, and S. Jacobsen. 2014. Integrating role of ethylene and ABA in tomato plants adaptation to salt stress. Sci. Hort. 172:109-116.

Bazihizina, N., E.G. Barrett-Lennard, and T.D. Colmer. 2012a. Plant growth and physiology under heterogeneous salinity. Plant Soil 354:1-19.

Bazihizina, N., E.G. Barrett-Lennard, and T.D. Colmer. 2012b. Plant responses to heterogeneous salinity: Growth of the halophyte Atriplex nummularia is determined by the root-weighted mean salinity of the root zone. J. Exp. Bot. 63:6347-6358.

Bazihizina, N., T.D. Colmer, and E.G. BarrettLennard. 2009. Response to non-uniform salinity in the root zone of the halophyte Atriplex nummularia: Growth, photosynthesis, water relations and tissue ion concentrations. Ann. Bot. 104:737-745.

Bernstein, L. and L.E. Francois. 1973. Leaching requirement studies: Sensitivity of alfalfa to salinity of irrigation and drainage waters. Soil Sci. Soc. Amer. J. 37:931-943.

Bingham, F.T. and M.J. Garber. 1970. Zonal salinization of the root system with $\mathrm{NaCl}$ and boron in relation to growth and water uptake of corn plants. Soil Sci. Soc. Amer. J. 34:122-126.

Chen, S., Z. Zhang, Z. Wang, X. Guo, M. Liu, Y.A. Hamoud, J. Zheng, and R. Qiu. 2016. Effects of uneven vertical distribution of soil salinity under a buried straw layer on the growth, fruit yield, and fruit quality of tomato plants. Sci. Hort. 203:131-142.

Cuartero, J. and R. Fernández-Muñoz. 1998. Tomato and salinity. Sci. Hort. 78:83-125.

Dara, A., B.A. Moradi, P. Vontobel, and S.E. Oswald. 2015. Mapping compensating root water uptake in heterogeneous soil conditions via neutron radiography. Plant Soil 397:1-15.

de Freitas, S.T., K.A. Shackel, and E.J. Mitcham. 2011. Abscisic acid triggers whole-plant and fruit-specific mechanisms to increase fruit calcium uptake and prevent blossom end rot development in tomato fruit. J. Exp. Bot. 62:2645-2656.

Demidchik, V. and F.J. Maathuis. 2007. Physiological roles of nonselective cation channels in plants: From salt stress to signalling and development. New Phytol. 175:387-404.

Dong, H., X. Kong, Z. Luo, W. Li, and C. Xin 2010. Unequal salt distribution in the root zone increases growth and yield of cotton. Eur. J. Agron. 33:285-292.

Dong, H., W. Li, W. Tang, and D. Zhang. 2008 Furrow seeding with plastic mulching increases stand establishment and lint yield of cotton in a saline field. Agron. J. 100:1640-1646.

Ebrahimi, R. and S.C. Bhatla. 2012. Ion distribution measured by electron probe X-ray microanalysis in apoplastic and symplastic pathways in root cells in sunflower plants grown in saline medium. J. Biosci. 37:713-721. 
Flores, P., M. Angeles Botella, V. Martínez, and A. Cerdá. 2002. Response to salinity of tomato seedlings with a split-root system: Nitrate uptake and reduction. J. Plant Nutr. 25:177-187.

Gama, P., S. Inanaga, K. Tanaka, and R. Nakazawa. 2007. Physiological response of common bean (Phaseolus vulgaris L.) seedlings to salinity stress. Afr. J. Biotechnol. 6:79-88.

Girija, C., B.N. Smith, and P.M. Swamy. 2002. Interactive effects of sodium chloride and calcium chloride on the accumulation of proline and glycinebetaine in peanut (Arachis hypogaea L.). Environ. Exp. Bot. 47:1-10.

He, F., Q. Chen, R. Jiang, X. Chen, and F. Zhang. 2007. Yield and nitrogen balance of greenhouse tomato (Lycopersicum esculentum Mill.) with conventional and site-specific nitrogen management in Northern China. Nutrient Cycl. Agroecosyst. 77:1-14.

Hilge, M. 2012. $\mathrm{Ca}^{2+}$ regulation of ion transport in the $\mathrm{Na}^{+} / \mathrm{Ca}^{2+}$ exchanger. J. Biol. Chem. 287:3164131649 .

Ho, L.C., P. Adams, X.Z. Li, H. Shen, J. Andrews, and Z.H. Xu. 1995. Responses of Ca-efficient and Ca-inefficient tomato cultivars to salinity in plant growth, calcium accumulation and blossom-end rot. J. Hort. Sci. 70:909-918.

Ho, L.C. and P.J. White. 2005. A cellular hypothesis for the induction of blossom-end rot in tomato fruit. Ann. Bot. 95:571-581.

Imada, S., N. Matsuo, K. Acharya, and N. Yamanaka. 2015. Effects of salinity on fine root distribution and whole plant biomass of Tamarix ramosissima cuttings. J. Arid Environ. 114:84-90.

Ityel, E., A. Ben-Gal, M. Silberbush, and N. Lazarovitch. 2014. Increased root zone oxygen by a capillary barrier is beneficial to bell pepper irrigated with brackish water in an arid region. Agr. Water Mgt. 131:108-114.

Ityel, E., N. Lazarovitch, M. Silberbush, and A. Ben-Gal. 2012. An artificial capillary barrier to improve root-zone conditions for horticultural crops: Response of pepper plants to matric head and irrigation water salinity. Agr. Water Mgt. 105:13-20.

Keiser, J.R. and R.E. Mullen. 1993. Calcium and relative humidity effects on soybean seed nutrition and seed quality. Crop Sci. 33:1345-1349.

Kong, X., Z. Luo, H. Dong, A.E. Eneji, and W. Li. 2011. Effects of non-uniform root zone salinity on water use, $\mathrm{Na}+$ recirculation, and $\mathrm{Na}+$ and H+ flux in cotton. J. Exp. Bot. 63:2105-2116.

Latef, A.A.H.A. and H. Chaoxing. 2011. Effect of arbuscular mycorrhizal fungi on growth, mineral nutrition, antioxidant enzymes activity and fruit yield of tomato grown under salinity stress. Sci. Hort. 127:228-233.

Lu, S., T. Li, and J. Jiang. 2010. Effects of salinity on sucrose metabolism during tomato fruit development. Afr. J. Biotechnol. 9:842-849.

Lycoskoufis, I.H., D. Savvas, and G. Mavrogianopoulos. 2005. Growth, gas exchange, and nutrient status in pepper (Capsicum annuum L.) grown in recirculating nutrient solution as affected by salinity imposed to half of the root system. Sci. Hort. 106:147-161.

Maggio, A., S. De Pascale, G. Angelino, C. Ruggiero, and G. Barbieri. 2004. Physiological response of tomato to saline irrigation in longterm salinized soils. Eur. J. Agron. 21:149-159.

Minhas, P.S. and R.K. Gupta. 1993. Conjunctive use of saline and non-saline waters. I. Response of wheat to initial salinity profiles and salinisation patterns. Agr. Water Mgt. 23:125-137.

Morard, P., L. Lacoste, and J. Silvestre. 2000. Effects of calcium deficiency on nutrient concentration of xylem sap of excised tomato plants. J. Plant Nutr. 23:1051-1062.

Munns, R. and M. Tester. 2008. Mechanisms of salinity tolerance. Annu. Rev. Plant Biol. 59:651-681.

Pitman, M.G. 1982. Transport across the roots. Q. Rev. Biophys. 15:481-554.

Qiao, H.L., X.J. Liu, W.Q. Li, and W. Huang. 2006. Effects of straw deep mulching on soil moisture infiltration and evaporation. Bull. Soil Water Conserv. 4:34-38. (In Chinese with English abstract).

Reina-Sanchez, A., R. Romero-Aranda, and J. Cuartero. 2005. Plant water uptake and water use efficiency of greenhouse tomato cultivars irrigated with saline water. Agr. Water Mgt. 78:54-66.

Rengasamy, P. 2006. World salinization with emphasis on Australia. J. Exp. Bot. 57:1017-1023.

Rooney, D.J., K.W. Brown, and J.C. Thomas. 1998. The effectiveness of capillary barriers to hydraulically isolate salt contaminated soils. Water Air Soil Pollut. 104:403-411.

Salama, R.B., C.J. Otto, and R.W. Fitzpatrick. 1999. Contributions of groundwater conditions to soil and water salinization. Hydrogeol. J. $7: 46-64$.
Shalhevet, J. 1994. Using water of marginal quality for crop production: Major issues. Agr. Water Mgt. 25:233-269.

Sonneveld, C. and C. de Kreij. 1999. Response of cucumber (Cucumis sativus L.) to an unequal distribution of salts in the root environment. Plant Soil 209:47-56.

Sun, Y., H. Feng, and F. Liu. 2013. Comparative effect of partial root-zone drying and deficit irrigation on incidence of blossom-end rot in tomato under varied calcium rates. J. Exp. Bot. 64:2107-2116.

Suzuki, K., M. Shono, and Y. Egawa. 2003. Localization of calcium in the pericarp cells of tomato fruits during the development of blossom-end rot. Protoplasma 222:149-156.

Tabatabaie, S.J., P.J. Gregory, and P. Hadley. 2004. Uneven distribution of nutrients in the root zone affects the incidence of blossom end rot and concentration of calcium and potassium in fruits of tomato. Plant Soil 258:169-178.

Taylor, M.D., S.J. Locascio, and M.R. Alligood. 2004. Blossom-end rot incidence of tomato as affected by irrigation quantity, calcium source, and reduced potassium. HortScience 39:1110-1115.

Van Ieperen, W. 1996. Effects of different day and night salinity levels on vegetative growth, yield and quality of tomato. J. Hort. Sci. 71:99-111.

Zekri, M. and L.R. Parsons. 1990. Response of split-root sour orange seedlings to $\mathrm{NaCl}$ and polyethylene glycol stresses. J. Exp. Bot. 41:35-40.

Zhang, L., G.D. Ding, X.Y. Wang, M.Y. Zhao, Y. Guo, L.W. Wei, and W.J. Liang. 2010. Effect of sand layer on soil water and salt movement in saline land. J. Agr. Res. Arid Areas 28:197200. (In Chinese with English Abstract).

Zhao, Y., Y. Li, J. Wang, H. Pang, and Y. Li. 2016. Buried straw layer plus plastic mulching reduces soil salinity and increases sunflower yield in saline soils. Soil Tillage Res. 155:363-370.

Zhao, Y., H. Pang, J. Wang, L. Huo, and Y. Li. 2014. Effects of straw mulch and buried straw on soil moisture and salinity in relation to sunflower growth and yield. Field Crops Res. 161:16-25.

Zheng, Q.S., H.Y. Liu, X.H. Long, Z.P. Liu, D.D. Liu, and Y.Y. Gao. 2010. Effects of salt stress on ionic absorption and distribution of rapeseed seedlings. Chin. J.Oil Crop Sci. 31:65-70. (In Chinese with English Abstract). 